\title{
Engendering Identity - The Discourse of Familial Education \\ in Anne Bradstreet and Marie de l'Incarnation
}

Thou ill-form'd offspring of my feeble brain,

Who after birth did'st by my side remain,

Till snatcht from thence by friends, less wise then true

Who thee abroad, expos'd to publick view,

Made thee in raggs, halting to th'press to trudg,

Where errors were not lessened (all may judg)

- Anne Bradstreet, "An Author to her Book" (1678).

In her American Triptych, Wendy Martin epitomizes the traditional feminist criticism of Anne Bradstreet's poetry when she identifies "An Author to her Book" as the moment when Bradstreet begins to "view her daily experience as a valid subject for her art." 1 Martin's judgment reinforces a division, posited much earlier by Adrienne Rich, between Bradstreet's early, purportedly masculine and derivative, verse and her later, more successful, domestic poetry. This division, since supported by numerous critics, draws its rhetorical strength from an equation of the vitality of Bradstreet's later, domestic poems with their putative originality and authenticity, what Rich calls her "personal history [of] marriage, childbearing, [and] death.", Though the intent of such criticism is to claim Bradstreet as a proto-feminist whose work helped to establish female experience as a fit subject for poetry, this reads like a rather more sexist 
formula: women should write about the private world they know — family and household — rather than the public realm of politics and history.

While critics such as Philip Round and Ivy Schweitzer have more recently reclaimed the political and even polemical significance of Bradstreet's poetry, they have largely reaffirmed this divide. ${ }^{3}$ As Tamara Harvey suggests, Round and Schweitzer find “double-voiced displays of poetic, personal, or female power" in the earlier poems, and thus still see in them in a kind of literary cross-dressing - the female poet ironically winking at us from behind a false beard and mustache, as it were. ${ }^{4}$ Further, both Schweitzer and Round deemphasize Bradstreet's own role in the production of her poetry, representing it as something appropriated from her by her male Puritan interlocutors, especially her brother-in-law, John Woodbridge. The combined effect of these critical moves is to position Bradstreet as an isolated phenomenon - the lone woman poet on the American frontier - rather than part of a larger, transatlantic community of European authors, both male and female, whose work engages the complex issues raised by the European colonization of the Americas. ${ }^{5}$ By insisting that we see Bradstreet as a rara avis, both the traditional and the revisionist criticism obscure those aspects of her writing that truly set her apart: her creative and provocative melding of religious, political, and domestic discourses to produce a potent vision of the relationship between colony and metropole as familial rather than heterosexual in nature.

It is, I suggest, only by reading Bradstreet's poetry alongside that of contemporary authors, both male and female, on both sides of the Atlantic, that we can properly understand its broader significance. ${ }^{6}$ Such a reading will allow us to see how Bradstreet links sexual and cultural 
reproduction, thereby cementing the family as the primary locus of identity development — at an individual and a communal level—and, more particularly, smoothing over potential dissonances between her (Puritan) religious identity and her (English) national identity. While critics such as Harvey and Patricia Pender have demonstrated how Bradstreet's work fits within a larger body of English language writing by men and women on both sides of the Atlantic, however, I want to highlight Bradstreet's place in an international discursive shift fueled by the developing European understanding of the colonization of the Americas. In order to do this, I will examine her poetry alongside the writings of Marie de l'Incarnation, a French nun who established the first educational mission for women (both natives and European transplants) in New France. ${ }^{7}$

De l'Incarnation's writings, like Bradstreet's, bear witness to an ongoing shift in the European understanding of the relationship between colony and metropole. De l'Incarnation also resembles Bradstreet in the way she deploys the symbolic resonances of the family to help reproduce traditional religious and national identities in the "New World." Unlike Bradstreet, however, de l'Incarnation's use of this rhetoric of familial education ultimately leads her to question the appropriateness of linking national and religious identities so firmly. As Carla Zecher suggests, de l'Incarnation's religious mission ultimately “decentered some of the nationalistic impetus of the colonizing enterprise," and thereby helped to produce "a new kind of French cultural identity" based, in part, on the blending of French and Native American cultural practices. $^{8}$

The fear of precisely such a destabilization of national and religious identities animates much early colonial writing throughout the Americas-English, French, Spanish, Dutch and 
otherwise - with earlier adventurer-explorers often focusing on refuting the climatological theories of national character popularized by political philosophers like Jean Bodin. By the time that Bradstreet, de l'Incarnation, and others were writing from established (if only recently-so) colonies such as New England and New France, however, colonization no longer simply meant thinking about the European men and women transplanting to what would be a "New" France or a "New" England, but also about the children who would be born there, and might perhaps even return to the metropole. One can see the ramifications of the colonial project slowly, belatedly, taking shape in the metropolitan mind, leading to fear of the emergence of that class of people the Spanish were already calling "creoles." And so we see Bradstreet and de l'Incarnation turn away from many of the concerns of earlier authors in order to highlight education, particularly education within a familial setting, as the means by which national and religious identities can be successfully reproduced in the North American colonies. What we find instead of the lone, male explorer performing his cultural identity to a native audience is the family—particularly the nuclear family — singled out as the site of education, with the maternal figure occupying the role of instructor, such that a fundamental symbolic link is made between sexual and cultural modes of reproduction.

Bradstreet and de l'Incarnation's regendering of the discourse of colonial identity has significant effects. Firstly, it shifts attention away from the hierarchical, even divisive, class identities that remain central to earlier male authors by taking politics out of the sphere of male competition. Then, simultaneously, it positions a particular set of religious practices and beliefs as a means to secure communal integrity. Finally, and perhaps most importantly for later discourses of national identity, it organizes the discursive connections between national politics, religion, and 
collective identity around the figure of a mother instructing her children in proper moral behavior.

Reading "The Author to her Book" in terms of this educational paradigm foregrounds its contemporary political resonances, making it possible to read the poem as part of Bradstreet's ongoing concern about the relationship between Old and New England, rather than her assertion of a new, authentically female voice. To draw out the political and religious implications of this poem, we particularly need to pay attention to its rhetorical constructedness - precisely those puns, metaphors, and other figures that are apt to be dissolved into the authentic, literal voice that Rich and Martin find in Bradstreet's later verse. Rather than reading this poem as a crux between two phases in Bradstreet's career, then, I want to insist that it is typical of all her poetry —indeed, all of her writing — in its use of domestic tropes to address political purposes.

In the poem, Bradstreet characterizes her book as a child of unspecified gender and sex. She then expressing concern about how her book will be received by the critics, especially because her poetry was first "expos'd to public view" without her consent, having been published in London from a manuscript copy secreted across the Atlantic by her brother-in-law, John Woodbridge. ${ }^{10}$ Woodbridge even acknowledges, in his "Epistle to the Reader," that Bradstreet "resolved [these poems] should never in such a manner see the sun." ${ }^{, 11}$ While Woodbridge's "such manner" implicitly refers to the act of publication, Bradstreet's "Author to her Work" exhumes another possible meaning by insisting on her attempts to "amend" her book-child's "blemishes" before she returns it to public view, suggesting that her resolution is not against her 
poems' publication, but against their appearing in public before they have been properly educated. $^{12}$

Where Woodbridge's “Epistle” aims to depoliticize the publication of Bradstreet's poetry by downplaying her authorial role, Bradstreet repoliticizes it on her own, domestic terms, offering us a crash course in what we might call "poetic pedagogy." Thus, while Bradstreet expresses shame at her "ill form'd offspring," she acknowledges her maternity rather than casting the child out. Instead, Bradstreet insists on the possibility of improving her book-child by "stretching [its] joynts to make [it] even feet" and "dress[ing]" it "in better trim." ${ }^{\prime \prime}$ These puns provoke a series of reinforcing associations: the appropriate gait and attire of a respectable English person overlap with the appropriate meter and diction of English poetry, producing a figurative evocation of a text that knows how to behave itself. Bradstreet, in amending her poetry, teaches it its manners, but she also teaches us something about the role of education in governing the transatlantic relationship between the metropole and the colony: to be properly English, the colonists have to reproduce proper English customs, and in order to reproduce those customs, they have to model them for their children to imitate in their turn.

What Bradstreet's poem lays bare, then, is how the rhetoric of colonization shifted from the earlier texts of male explorer-adventurers such as Sir Walter Raleigh and John Smith precisely because the source of the anxiety about colonization itself shifted from the ordeals of crossing the Atlantic and the strangeness of "first contact" with Native Americans to the difficulties of establishing a permanent population of "native" Euro-Americans that maintains a properly European identity. Where, as Louis Montrose has shown, early explorers like Raleigh use sexual 
puns to create a masculine symbolism of the discovery and conquest of a feminized and eroticized America, Bradstreet gives us, in her poetry, a feminine and familiarized America. The New World becomes, as Pender has argued, quite literally the daughter of the Old one, replacing a heterosexual paradigm with a familial one. ${ }^{14}$

By placing Bradstreet and de l'Incarnation side-by-side, we can begin to see how this shift is part of a larger transatlantic discursive development driven by the rhetorical demands of the colonization of the Americas. Furthermore, we can demonstrate that Bradstreet's writings are not the strange and marvelous singularity that they are often held to be, but rather part of a larger body of writing by women that both takes part in and challenges the dominant paradigms of seventeenth-century political philosophy as it applied to the colonization of North America.

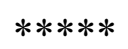

Where Francis Bacon emphasizes education as the product of a scientific method based on inductive logic_- "I open and lay out a new and certain path for the mind to proceed in, starting directly from the simple sensuous perception"-Bradstreet and de l'Incarnation conceive of education as a process in which correct behavior is modeled and then imitated. ${ }^{15}$ In a letter to her nephews, for example, de l'Incarnation instructs them that "[1]e vray moyen de vivre dans ce haut état [l'état de grâce] ... c'est d'observer Ses commandemens, de frequenter souvent les Sacremens \& de regler vos moeurs sur les exemples de JESUS-CHRIST" ["The true way to live in this high state [the state of grace] ... is to observe His commandments, to partake often of the Sacraments, and to measure your mores against the example of Jesus Christ"]. ${ }^{16}$ Thus, while 
Bradstreet and de l'Incarnation hardly espouse the overt theatricality of early adventurerexplorers like John Smith, their writing is, in Homi Bhabha's terms, "performative," inasmuch as it relies on the power of an iterative representational strategy to produce collective identity. ${ }^{17}$

In Bradstreet's poetry, as we saw in "The Author to her Book," this iterative or recursive representational strategy feeds off of the productive tension between literal and figurative levels of meaning. By moving back and forth between the two, Bradstreet is able to draw attention to the status of her writing as a representation. Thus, as Bradstreet represents education taking place, she is also educating her readers, encouraging her readers to identify with the figures in her poem. The impulse to identify, however, requires that a reader first recognize a gap between her or himself and the representation that can then be bridged through the learning process. This recognition, then, opens up what Bhabha, borrowing from Raymond Williams, would call a "space of cultural signification" wherein "residual and emergent meanings and practices ... in the margins of the contemporary experience of society" can be represented. ${ }^{18}$ Yet where Williams and Bhabha implicitly oppose the emergent "meanings and practices" that such a performative discourse enables to the preservative or conservative ones, Bradstreet demonstrates that these two terms cannot be so readily opposed, since the emergent aspects of her writings operate in the service of a project to conserve a traditional English identity.

Such a combination of emergence and conservation is in truth what predicates the recursivity of this discursive process. If Bradstreet opens up a new representational space in her portrayal of families as the site of education, it is precisely in order to collapse the distance between representation and embodied reality so as to better preserve an orthodox religious identity-a 
religious identity, it should be noted, upon which English national identity, in Bradstreet's understanding, depends. The religious aspect of Bradstreet's writing should, in particular, signal to us the fraught representational dynamics at work here. As Jim Egan notes, "Bradstreet never presumes to overcome the absolute difference between spiritual and material states of being."19 And yet, Bradstreet uses writing to repeatedly stage that difference and its collapse, engaging in an iterative calculus by which the material is symbolically brought towards the divine without erasing the difference between them. Textual representation becomes an intermediate space between the spiritual and the material, allowing for a metaphorical translation to take place between the two. This translation follows a chiasmatic logic: the written word occupies the place of the material vis-à-vis the spiritual, while taking that of the spiritual in opposition to the material. Writing, in other words, allows Bradstreet to clothe the invisible world of the spirit in the guise of the material; thus clothed, she can offer us a figuration of that world for us to model ourselves after.

Taking Bradstreet's poems to her husband as an example of how this dynamic plays out, we might, at first glance, note several passages that seem to argue for an embodied reality behind the text. In "Before the Birth of one of her Children," for example, Bradstreet closes with the lines "And kiss this paper for thy loves dear sake, | Who with salt tears this last Farewel did take."20 These words invite us to imagine Simon Bradstreet sitting at his writing desk, his eyes fixed upon a pair of small blotches on the paper that record the traces of this sentiment, adding to them himself as he mourns the death of his wife. As Gary Schneider reminds us, however, these words are part of "a specialized epistolary rhetoric" that produces in its recipient an "imaginative sympathy so that epistolary contact maintains communicative and affective integrity and 
efficacy"; in other words, their focus is not on representing reality so much as producing it. ${ }^{21}$ Further, as Gina Bloom argues, the very composition of these poems is not simply "a display of affection" but, “in fact, a duty,” prescribed by such Puritan ministers as William Gouge. ${ }^{22}$ Bradstreet's poems, then, convey not only a personal meaning, but also a larger social and religious meaning. Though certain lines in these poems evince a Donnian syntax- "If ever two were one, then surely we"- - her depiction of the relationship between husband and wife primarily operates in dialogue with writings about love and marriage in genres that more explicitly intervene in contemporary political debates - sermons, religious tracts, and conduct manuals. As Bloom demonstrates, this dialogue is truly a two-way affair; Bradstreet, she notes, often uses vocabulary that Puritan marriage doctrine suggests is inappropriate for wives to apply to their husbands, such as "dear" and "love," since these terms imply equal status, rather than placing the man at the head of the family. ${ }^{23}$ This reconfiguration of the marital hierarchy suggests some of the emergent aspects of Bradstreet's rhetoric, particularly her feminization of political discourse, as seen in her "In honour of that High and Mighty Princess, Queen Elizabeth" and her "Dialogue between Old England and New."

Yet, for all Bradstreet tweaks the rhetoric of marital love here, the primary message these poems communicate remains a thoroughly conservative one. At a mundane level, the poems insist on the need for a married couple to live together, something which the Puritans greatly encouraged as a means to "avoid fornication." 24 Likewise, in "Before the Birth," Bradstreet indicates that a major role of husband and wife is to raise their children and protect them from harm, imprecating her husband to "Look to my little babes my dear remains" and "protect [them] from step Dames injury. ${ }^{25}$ Finally, the poems position marriage as a means for conceptualizing abstract religious 
issues; thus, in "To my Dear and loving Husband" and "A Letter to her Husband, absent on Publick employment," Bradstreet repeatedly invokes the absent presence of her husband, obliquely figuring the absent presence of God Himself.

As Bloom notes, "[m]atrimony, for the Puritans, was more than the sum of its parts. It was the primary way in which humans could embrace the full grace of God, and it was the incarnation of the Holy Spirit. ${ }^{, 26}$ In this sense matrimony is like writing, since it serves as an intermediate term between the material world and the spiritual one, bringing the two into a metaphorical relationship, just as her husband becomes the "sweet Sol" who warms her "earth" in the "Letter to her Husband."27 And Bradstreet's writing itself serves to reinforce the institution of marriage in two ways: firstly, by "manifesting" the "mutual concern" of Bradstreet and her husband for each other, and, secondly, by "effecting" that selfsame concern. ${ }^{28}$ These two terms correspond to the two movements in the chiasmatic process of representation at work in Bradstreet's writing: the integrity of their marriage is manifested in the transformation of the material into the spiritual, and effected by the movement from spiritual to material. What Bradstreet teaches us in these poems is that producing and maintaining the proper relationship between husband and wife helps to bridge the difference between the spiritual and material, a message further reinforced by rhetorical implication of "Before the Birth" that the speaker is speaking from beyond the grave.

As her marriage poems already begin to show us, the key figure of Bradstreet's rhetoric of education is the integral nuclear family. This figure is most explicitly delineated, however, in a series of epitaph poems, written upon the death of her parents, children, and grandchildren. Because these poems deal with death, which in Bradstreet's conception is quite literally the 
translation from the material world into the spiritual, they offer a perfect vehicle for her to convey the importance of education as a means of achieving a successful movement from earth to heaven - a movement, that is, that maintains the integrity of the family. Though the general tenor of these epitaph poems is the acceptance of God's will—so emphatically expressed that modern readers may be hard-pressed to see anything else in them - they are in fact quite prominently marked by emotive touches that evince her symbolic investment in her family. Thus, in a poem dedicated to one of her grandchildren, she writes "[w]ith troubled heart \& trembling hand" before coming at length to the conclusion that her "throbbing heart" should be cheered by the fact that the child is "with [its] Saviour ... in endless bliss." ${ }^{29}$ With Schneider's observations about the epistolary rhetoric of sympathy in mind, the purpose of these figures becomes clear: Bradstreet provides a model, here, for how one ought to behave as a member of a family, seeking to reproduce the appropriate attitudes in her audience, and thereby produce communal integrity through the symbolic reintegration of the family in heaven.

Taking these poems as a group, however, we find that Bradstreet hardly takes the ease of moving from one realm to the other for granted, particularly when the "translation" of an entire family is at stake. In them she often struggles to account for God's actions in a rhetorically effective fashion. In the end, Bradstreet is often left with the mere blandishment that all her dead relations must be in heaven, reunited for eternity, though a note of doubt slips into the poem for her son when she says that her daughter-in-law is "[a]11 freed from grief (I trust) among the blest." ${ }^{\text {30 At }}$ one level this line can certainly be read as a doctrinally appropriate indication of the limits of embodied human knowledge; at another, however, it speaks to the potential, and problematic, divide between God's will and the continued unity of the family. Given the central symbolic 
importance of the family in Puritan society in general, and Bradstreet's writing in particular, such a divide represents a potential tension between religious and national identity as well.

The question of whether saving grace could be transmitted from parent to child was one of the most hotly contested in Puritan New England in the seventeenth century. The material effects of this theological debate appeared in a series of controversies over the main sacraments of the Puritan church: baptism, communion, and, most particularly, the recounting of a religious conversion experience. In authorized New England Puritan practice before 1662, only the children of full members of the church could be baptized, receiving the grace transmitted thereby, and full church membership was extended only to those who could account for their spiritual regeneration sufficiently well to receive the approval of other church members. At the Cambridge Synod of 1662, however, the Puritan community in New England accepted what was known as the Half-way Covenant, which allowed for the baptism of children of covenanted church members - those, that is, who had received baptism themselves, but not produced a conversion narrative. The "half-way" of the Half-way Covenant refers to the fact that baptism was understood by the Puritans as offering merely the "conditional promise" of God's grace, so that baptized children were only "half saved." ${ }^{31}$ Despite the acceptance of the Half-way Covenant at the Synod, the issue remained contentious throughout the remainder of the century. Thus Solomon Stoddard argued for further liberalization at the Reforming Synod of 1679; meanwhile, Cotton Mather was still lobbying conservative members of Boston's Second Church to accept the Half-way covenant in $1692 .{ }^{32}$ 
Against this discursive background, the symbolic difficulty Bradstreet has negotiating between her relationship to her family and her relationship to God in her epitaphs comes as little surprise. These poems evince her ongoing anxiety about the relationship between the material and the spiritual, raising the question of how best to move from one realm to the other when the absolute difference between them, however symbolically reduced, remains intact. If death alone is hardly, for Bradstreet, a sufficient means for moving properly from one state to the other, then birth, too, is no guarantor of heaven, a point most clearly expressed in one of Bradstreet's "Meditations Divine and Morall," in which she points out that "good parents have had bad children, and ... bad parents have had pious children."33 Thus, while many of Bradstreet's poems downplay the significance of experience, she repeatedly insists upon the role of education as a means for securing grace.

The transformative role of education that Bradstreet credits to education is made most forcefully and explicitly clear in her epitaph poems to her parents. In "To the Memory of my dear and ever honoured Father" Bradstreet calls him "my Father, Guide, Instructor too," language echoed in “An EPITAPH on my dear and ever honoured Mother," where the latter is called "A true Instructer of her Family. ${ }^{, 34}$ Both poems go on to list the good behaviors and deeds of Bradstreet's parents, and the poem to her father ends by rhetorically closing the gap between the embodied world of the family and the spiritual one, "[h]is pious Footsteps, followed by his race, | At last will bring us to that happy place. ${ }^{35}$ Ultimately, education—or at least the rhetorical invocation of education - plays the role that experience does for Bacon: the task of parents as instructors to their children is to provide examples that they can follow into heaven. 
I insist here on the possibility of reading these poems as though they are simply invoking education rather than actively educating because of the reflexive qualities of Bradstreet's own instructive writings to her children, which emphasize form over content. In the introduction to her manuscript "Mediations Divine and Morall," she downplays the value of her advice, explicitly aiming to "avoyd incroaching upon others conceptions because [she] would rather leave [her children] nothing but [her] owne, though in value they fall short of all in this kinde." Bradstreet seems, here, to be disavowing the practical effectiveness of her instruction: her children, she says, could find better elsewhere. Yet she quickly flips this logic on its head by pointing out that, as she is their mother, her teachings are likely to "be better pris' $d$ by [her children,] for the Authors sake. ${ }^{, 36}$ With these words, Bradstreet positions herself at the center of her children's education, asserting that sentimental attachment supersedes any consideration of value or merit. Her meditations themselves bear out this logic, insisting at several points that parents must learn to "fit their [children's] nurture according to their Nature," and, more strikingly, repeatedly deploying the relationship between parent and child as a symbol of other kinds of relationship, such as that between human beings and God. ${ }^{37}$ The meditations thus insist upon the figure of the family as both a means of moral and religious instruction, and as instruction's symbolic seat. To use the old-fashioned poetic terminology, the vehicle of these maxims overtakes the tenor: the lesson is contained not in what is taught, but in how it is being taught.

That lesson — that the family is the key institution in the instruction of children, and thus the means by which an orthodox religious and national identity are reproduced—offers a novel detour around the discursive impasse at work in the debates over the Half-way Covenant. By 
insisting upon the instructional role of parents in producing properly religious children who can follow them to heaven, Bradstreet dodges the suspect claim, associated with Catholicism, that the grace transferred from parent to child at birth was wholly secured by infant baptism. At the same time, Bradstreet's writing hollows out the content of that instruction, reducing the emphasis on the particular religious customs at work in securing identity and leaving us with the image of the extended nuclear family reunited in heaven. The religious egalitarianism inherent in this vision jars with our conventional notion of the Puritans as an exclusive community of fire and brimstone-breathing bigots, though it jibes with the associations made by Max Weber, and echoed by Nancy Armstrong and Leonard Tennenhouse among others, between Puritan ideology and the rise and expansion of a bourgeois middle class. ${ }^{38}$ Indeed, viewed against the rank-based distinctions at work in earlier colonial authors such as Raleigh and Smith, the social organization imagined by Bradstreet is distinctly flat in character, with uniformity of religious and national identity taken almost for granted, leaving the gendered and generational distinctions between family members as the sole means to differentiate between people.

Even these distinctions are only loosely grounded, since the entire purpose of Bradstreet's discourse is for each generation to hew to the model offered by the previous one, and thereby remove whatever distinction existed between them. Perhaps by calling upon the conventional distinction between gender and sex I can further illuminate my reasoning here. Compared with many of her contemporaries, both Puritan and otherwise, Bradstreet's poetry is relatively ungendered, as Bloom's assessment of her vocabulary would indicate. In a sense, her regendering of politics enables a kind of ungendering, inasmuch as it flattens the distinctions between male and female discourse. I would ultimately suggest, however, that Bradstreet's 
writing is not so much ungendered as unsexed — which might well explain what Egan calls the "antiseptic quality of [Bradstreet's] secular love poems." 39 In other words, while her writing draws upon convenient categorical distinctions such as gender, her purpose in doing so is to produce a reality in which those distinctions no longer exist.

Thus there is a modicum of gendering that slips into Bradstreet's particular accounts of the qualities fathers and mothers are supposed to inculcate in their offspring - she emphasizes her mother's ordering of the household in opposition to her father's role in founding the Commonwealth of Massachusetts, for example, though she also draws attention to her mother's public speaking - but in her poetry these gender differences do not necessarily attach to sexed bodies as such, since they operate first and foremost as rhetorical figures. The titular sisters of the poem "The Flesh and the Spirit," for example, could easily be made into brothers without any harm being done to the sense. Ungendered, however, is not unengendered, as Spirit clarifies at the crux of this poem, indicating that she and Flesh are the children of different fathers: one "old Adam" and one "above." 40 With this rhetorical gesture, Bradstreet reverses our conventional arrangement of the real/fictive, literal/figurative poles: she gives us, on the one hand, a literal father, Adam, who is effectively fictive, and, on the other, a figurative father, God, who is the epitome and apex of being. The key here is her use of an intuitive alignment of embodiment with reality in order to portray the spiritual as a higher reality, which transforms the family into a mere metaphor for the true, spiritual family. And yet, as we have seen above, in becoming a metaphorical model for actual families, the educational family of Bradstreet's poetry helps to elevate them to the level of the spiritual family. 
The rhetoricity of Bradstreet's gendering is perhaps most apparent in her early poetry, especially "The Quarternions," which, as Harvey demonstrates, remotivate Galenic medical discourse in order to support a more egalitarian vision of the relation between the sexes. The genderings that interest me most in these poems, however, are not those given to disembodied entities such as "choler" and "phlegm," but rather those that could more convincingly be linked with sexed bodies. In her verses on the four seasons, for example, Bradstreet portrays "cleanly huswives" with their shelves "fill'd for winter time," and mowers and carters toiling in the summer sun. ${ }^{41}$ While these images clearly evoke a gendered division of labor, they also draw quite consciously upon a tradition of georgic and pastoral poetry extending backwards through Drayton and Spenser to Virgil and Lucretius, as signaled by the "whistling voyce" of the carter celebrating the end of his work-day, a voice that echoes those of Virgil's musical shepherds in the Eclogues. Bradstreet, in other words, is carefully following her models in these poems, concerning herself with reproducing an image of an orderly world.

These early poems are also more explicitly political in character, clearly situating Bradstreet's figure of the integral nuclear family in a national context. In truth, however, what these poems show us is the disintegration of the family as emblematic of the disintegration of the nation, with Bradstreet borrowing from Virgil again in her depiction of war and famine, and the chaos that follow upon them. Late in the first book of the Georgics, Virgil offers a glimpse of the effects of the intrusion of war upon the husbandry of the land:

Here the good and evil have changed places: so many wars in the world, so many forms of wickedness, no honor 
for the plow, farmers conscripted, the mournful fields untilled, and curved pruning hooks are beaten into unbending swords. Here Euphrates, there Germany goes to war; neighboring cities, flouting the laws they've both agreed on, take up arms. ${ }^{42}$

Aside from reversing our conventional image of swords being beaten into ploughshares, Virgil's poem suggests a fundamental opposition between agricultural production and war. Bradstreet, in the persona of "Earth," refigures this civil disintegration, imagining "The Corne, and Hay, both fall[ing] before they'r mowne, | And buds from fruitfull trees, before they'r blowne" leading to such dearth that "The husband knowes no wife, nor father sons." ${ }^{, 43}$ Bradstreet's imagery differs from Virgil's, then, in giving the destruction of the family a central place in this sequence of events. Yet, while Bradstreet is certainly thinking about gender here, the authority for these figures of speech comes from their central place in literary history—and, one might add, in contemporary English education— not from their connection to some kind of embodied experience. ${ }^{44}$

Rather than concentrate on sex, Bradstreet underlines the gender roles, showing us the connections between being a husband and husbandry, as it were. Bradstreet's cursory invocation of rape at several points in her poetry reinforces this unsexing. As Barbara J. Baines notes, the representation of rape in English writing of this period is "always political" because "[s]exual incontinence ... is the mark of misrule"; ${ }^{45}$ in Bradstreet's case, we might say that rape is in fact primarily political, since it operates as a symbol of political unrest, rather than being represented as an attack on an individualized, psychologized, and embodied person. Thus, when Bradstreet, 
later in the "Quarternions," portrays the destruction of family as the symbolic equivalent of the destruction of state, it becomes clear that her attention is focused on the disappearance of the distinctions between different family members, as when the incestuous and fratricidal rapist King Cambyses of Persia is called a "hellish Husband, Brother, Unckle, Sire."46 This looks like the same fear that the collapse of the categories of identity will lead to political anarchy that we find expressed in the work of Bradstreet's contemporaries on both sides of the Atlantic, but given Bradstreet's flattening of social distinctions, it would be more accurate to read it as the improper reproduction of those categories, though it clearly leads to the very same anarchy.

What are we to make, then, of this strange rhetorical method that elaborates differences only in order to collapse them? Bradstreet's writings, I have insisted, rely upon a series of figures of speech centered on the symbol of the family. These figures may not be grounded in material reality as such, but they are supposed to help create a reality, to produce the embodiment of a disembodied ideal. By placing the family at the nexus of a network of identity categories, Bradstreet suggests that it is the key to protecting those identities. Further, by portraying the family as the seat of education, Bradstreet suggests that it is the vehicle for reproducing those identities. All of these threads come together in her ultimate reconfiguration of the symbolic relationship between colony and mother country in "A Dialogue between Old England and New," which exposes the arbitrary nature of the hierarchical distinctions between this and that family member even as it demonstrates the role that family bonds play in opening up the possibility of education as a means to producing an orthodox identity. 
In this poem, written at the outset of the English Civil War, Bradstreet deploys many of the same figures that we have already located in her other writings — she represents Germany, in the wake of the Thirty Years War, for example, as a "barren heath" where "people [are] famish'd ... Wives forc'd [and] babes toss'd"- but the poem in which she deploys these figures constitutes a radical break in the traditional representation of the relationship between colony and metropole. ${ }^{47}$ The poem portrays "Old England" as wounded and weak, and "New England" as her help-meet, offering advice on how to improve her state. Old England tries to put New in her place by characterizing her as a limb, a symbolic gesture whose significance would not have been lost on contemporary readers. ${ }^{48}$ New England insists, however, that Old has not paid attention to her family duties by allowing Catholicism to spread unabated throughout the continent and paid the price by becoming infected herself. As both Pender and Egan note, this situation reverses the traditional paradigm of mother/daughter relations. Egan puts it best when he asks: "parents are supposed to observe their children, are they not, and when observed, present those children with an example to emulate?",49

And yet, while Bradstreet's poem is a departure in this way, it manages to recuperate this transformation by placing it within the rhetoric developed across the course of her poems. New England can provide Old with an example to emulate only because she herself is emulating the example Old England once offered. Thus, the preservation of identity relies on its being reproduced in an appropriate fashion. That the child teaches the mother in this poem reinforces Bradstreet's point: English political order has been overturned. Rather than the colony her metropolitan counterparts fear, where proper English men and women degenerate into savage beasts, New England provides exactly the sort of colony England needs, one destined to offer an 
example to the mother country precisely because New England's mothers have raised their children well, according to example. The copy, in other words, helps to guarantee the perfection of the original.

$* * * * *$

Juxtaposing the writings of a married Englishwoman with eight children to those of a cloistered French nun might seem counterintuitive, yet de l'Incarnation takes part in precisely the same mutation of the discourse of masculine adventuring into the discourse of familial education that I have identified in Bradstreet. The irony of this juxtaposition is that de l'Incarnation's writing is often more explicitly concerned with the quotidian details of daily existence than Bradstreet's, giving it a more recognizably domestic character. Further, de l'Incarnation's relationship with her son, who edited and published her works after her death, takes on greater contour in her writing than Bradstreet's with her children. This difference can perhaps be explained by their different situations; against the backdrop of a Puritan society focused on "Family Government," ${ }^{50}$ Bradstreet can take her audience's attention to daily domestic life for granted, while de l'Incarnation gives us such quotidian details in order to convince us of her domesticity. In the end, however, it may stem from a difference in purpose: unlike Bradstreet, who focuses primarily on the integrity of the nuclear family as a symbol for the continued integrity of an already existing country, de l'Incarnation symbolically expands the conception of family in order to justify the literal expansion of nation and religion through the colonial assimilation of native populations. 
Those scholars who have studied de l'Incarnation's life and writings most closely would certainly be surprised by my putting her alongside Bradstreet, since they tend to view the central event in her life — her departure for Canada — as an abandonment of her son, and thus of her role as a mother, as much as a departure for a "New World." Her two most recent biographer-critics, Marie Florine-Bruneau and Natalie Zemon Davis, have positioned her struggle with the decisions to become a nun and then to travel to Canada following her husband's death as the key to understanding her psyche. ${ }^{51}$ In truth, though, de l'Incarnation's writings evince much of the same concern about the division between the secular and divine worlds as Bradstreet's poetry. Thus, in her Relation, de l'Incarnation recounts her struggle with how to respond to her calling in great detail:

In a word, I was besieged on all sides and my natural love pressed upon me so sharply that it was as though my soul were being wrenched from my body. Nothing about my obligations concerned me except my love for my son. Furthermore, I never stopped hearing an inner voice which pursued me everywhere, saying, 'Hurry! It's time. It's not good for you to be in the world any longer.' These words made their point. ${ }^{52}$

The totally exclusivity of her religious calling and her secular life expressed in this passage"Nothing ... concerned me except love for my son"; "It's not good for you to be in the world any longer"- are further reinforced by the words that convey her state of mind at the very moment of her leaving to become a nun: "Watching [my son cry], it seemed to me that I was being cut in two." De l'Incarnation, then, faces much the same dilemma as Bradstreet, trying to maintain an 
integral identity while being pulled between the mundane, embodied world and that of the spirit. And yet, even at this most intense moment, she insists that she "did not let [her] emotions show" and focused on the fact that she was "[p]utting [her] son into the hands of God and the Blessed Virgin," suggesting the rhetorical devices that will enable her to symbolically bridge the gap between these disparate worlds. Much like Bradstreet, de l'Incarnation comes to use secular figures to represent higher spiritual realities to which the secular can then aspire through diligent imitation. $^{53}$

Hewing first to her consciously suppressed emotional response, we must recognize that the logic of modeling is at work here, too, since her justification for keeping her feelings hidden is precisely to prevent them from provoking a more intense response. Indeed, she indirectly admits to Martin, in her Relation of 1654, that she withheld her caresses from him when he was a child because she knew that she was destined to be a nun and wanted to minimize the emotional bond between them. ${ }^{54}$ While both her and her son's initial response to their separation demonstrate that this tactic was insufficient in and of itself, when coupled with de l'Incarnation's characterization of God, Jesus, and Mary as members of a holy family — and thus, by extension, her and her son's true family_ - it accounts for her actions in a much more convincing manner, and simultaneously produces the effect she desires: her son's own entry into religious orders.

The answer to the problem represented by her "abandonment" of her son, in other words, is de l'Incarnation's insistence on the literality of her familial relationship with God, Jesus, and Mary, as well as on the ability of that relationship to serve as a model not only to her Native American proselytes, but to her son as well. In a letter to her son written shortly after her arrival in Canada, 
for example, de l'Incarnation asks him: “Cet abandon ne vous a-il pas esté utille?” [“Hasn't this abandonment been to your advantage?"], pointing out that God promised her "qu'il auroit soin de vous" ["that He will take care of you"] and that Mary, "la Mère de la bonté" ["the Mother of goodness"], also "prendroit soin de vous" ["will take care of you"], particularly since Martin himself has taken her and her son, Jesus, "pour Mère \& pour Espouse, lorsque vous entrastes dans vos etudes" ["for Mother and for Spouse once you began your studies"]. ${ }^{55}$ According to de l'Incarnation's symbolic logic, this has indeed been to her son's advantage because Jesus and Mary are the true models for the "secular" family that her and her son constitute, and so, in taking them for "Mother" and "Spouse" in place of de l'Incarnation, he has brought himself closer to salvation. He has also, we should note, brought himself closer to his mother, since in joining the Benedictines Martin conforms to his mother's desire and to her example.

In this letter - and elsewhere in her writing - de l'Incarnation positions herself as the intermediary between Mary and Jesus and her son, since it is she who sends Martin the message that they will take care of him. Bruneau identifies this mediation as evidence of her "clerical rather than maternal authority in relation to" Martin, but I would argue that it is in fact evidence of her integration of those roles, as her particular insistence on the language of family relationships to characterize religious ones further indicates. ${ }^{56}$ Indeed, examining the meanings at work in de l'Incarnation's own name exposes how thoroughly she had bound the world of the spirit and the world of the flesh together in the symbol of the family as a justification for her role as an educator. 
As Davis notes, de l'Incarnation chose her religious name "since it was as the Word Incarnate that she had most often thought of Christ," and so, by choosing this name, positioned herself as a privileged apostle of the Word of God. ${ }^{57}$ The further resonances of "incarnation," which evokes the central Christian mysteries of the immaculate conception of Christ and his birth as the embodiment of spirit, draw our attention to the same dynamic of translation between spiritual and physical worlds that we saw at work in Bradstreet's poetry. Tying these associations together with those of de l'Incarnation's Christian name, Marie, her role as apostle overlaps completely with her role as mother; though she would never have presumed to take the (blasphemous) position of mother vis-à-vis Christ, she clearly took Mary as a model. In fact, it was Mary herself who, in a dream vision, had told de l'Incarnation of her apostolic mission, with God later confirming for her that '[c]'est le Canada que je t'ai fait voir; il faut que tu y aille faire une maison à Jesus et à Marie" ["It is Canada that I have shown you; you must go there to build a house for Jesus and Mary"]. ${ }^{58}$

Through this identification with Mary, de l'Incarnation genders the educational process much more definitively than Bradstreet ever does, though both authors clearly overturn the conventional tropes of (male) genius. Thus, Martin, in a discussion on the Song of Songs based on his mother's own notes, interprets women's breasts as a symbol of the capacity to teach, citing the metaphorical invocation of "le lait d'une sainte doctrine" ["the milk of sacred doctrine"]. ${ }^{59}$ Even if this citation does not come from directly de l'Incarnation's notes, which are no longer extant, Martin certainly could have found the same figure elsewhere in her writings, such as a letter she wrote to him in 1644 , in which she tells him of some "damoiselles qui ont sucé la vertu avec le laict de leur bonne mere" ["young women who have imbibed virtue with 
their mother's milk"]. ${ }^{60}$ In the place of male sexual conquest as the symbol of education, then, Bradstreet offers us a dialogue between mother and daughter, and de l'Incarnation—remotivating a conventional early modern trope - a mother suckling her child. De l'Incarnation's figure thus bring us ever closer to the modern conception of the family as the bridge between nature and culture, with the mother in particular singled out as the vehicle that translates us from one to the other, though we must remind ourselves that this is not the symbolic chasm that she intends to bridge with her writing and her instruction.

Indeed, as if to prove the success of her methods, and disprove those of her subsequent editors who would doubt his faithfulness to her words and intent, Martin provides an elaboration of her method in his introduction to her Retraites:

Ainsi je ne sçay point de livre en ce genre, qui soit d'un plus facile usage; car ceux qui s'en voudront servir, n'auront qu'à suivre celle qui la composé: ils pourront penser ce qu'elle a pensé, produire les affectations qu'elle a produites, faire les resolutions qu'elle a faites, parler à Dieu comme elle luy a parlé, se remplir de son esprit \& de ses sentimens; de la sorts ils feront les mémes oraisons qu'elle a faites, $\&$ il sera difficile d'en faire de plus saintes $\&$ de plus pures. ${ }^{61}$

In this passage, Martin effectively reproduces the rhetoric modeled for him by his mother, and thereby produces an even stronger sense of the recursivity of this educational method: in following de l'Incarnation's words, after all, her readers will be doing what Martin has already 
done. In fact, Martin's style raises this imitative logic to a new level, with the syntax of this passage mimicking, and thus reinforcing, the very process of mirroring that it represents. In his own account of how he treats his mother's writings, Martin openly addresses the changes he makes to her work, stating, in his preface to La vie, that "[i]l y a plus d'un Autheur; il y en a deux, \& l'un \& l'autre étoient necessaires pour achever l'Ouvrage" ["There is not one Author to this work; there are two ... [b]oth ... necessary to its completion"]. ${ }^{62}$ Martin further insists that "il n'y parle que comme un écho [de Marie de l'Incarnation]" ["He [the second author-i.e., Martin] speaks but as an echo [of the first, Marie de l'Incarnation]"]. ${ }^{63}$ While one may doubt how completely or accurately Martin echoes his mother, we must still acknowledge his choice of words is an interesting one, especially in light of de l'Incarnation's own insistence, in her letters and elsewhere, on the value of imitation as a means to moral improvement. Even an echo, we should note, follows a principle of selection, since only the loudest, most clearly articulated phrases are reproduced.

De l'Incarnation's own account of her religious development demonstrates how such selectivity is in fact a key aspect of an educational method based on modeling. Recounting her youthful religiosity, she notes how God gave her "une grande inclination à la fréquentation des sacrements" ["a profound desire for the reception of the sacraments"] — that is, those religious ritual practices imbued with the greatest symbolic significance, such as baptism, communion, and confession. ${ }^{64}$ The initial attraction of these practices comes from their striking sensual elements - as de l'Incarnation notes, she "[les] trouvais si beau et si saint que je ne voyais rien de semblable" ["found them incomparably beautiful and holy"] —and this attraction draws her into an accumulating and intensifying cycle of repetition: "tant plus j'approchais des sacraments, plus 
j'avais désir de m'en approcher" ["The more I approached the sacraments, the more I desired them"] ${ }^{65}$ Furthermore, this attraction is, for de l'Incarnation, at least initially distinct from any intellectual appreciation of the meaning of the sacraments, since, as she states quite explicitly, it is only when she had "devenue plus grande" that she was "capable de recevoir leur signification" [when she "grew up" she was "able to understand their meaning"]. ${ }^{66}$

The dynamics of this progress into deeper religious faith through ritual practice are well illumined by de l'Incarnation's observation that she "used to watch the posture of people who were praying" in Church and "feel urged by an interior spirit to withdraw to pray without even knowing what the interior spirit was or being acquainted with the words, 'interior spirit,' as I have already said. ${ }^{, 67}$ Though de l'Incarnation identifies the source of her impulse to pray as an interior one, it is the act of observing a behavioral model that, in fact, sets the process in motion; the interiority belatedly follows upon the action itself, a fact which de l'Incarnation's distinction between "knowing" and "being acquainted with the words" suggests that she understands. Imitation, in other words - and of words, too, we should note - produces the understanding requisite to the proper performance of religious identity. And, when understanding follows, it helps to reinforce the cumulative process of accoutumance, or "accustomization," already well under way: 'Plus j'avançais en conniassance, plus j'avais de touches et d'amour pour ces saintes ceremonies de l'Église" ["The more I understood them, the more I was filled with love for these holy ceremonies of the Church"]. ${ }^{68}$ It even helps propel de l'Incarnation towards her apostolic mission, since, feeling the love the sacraments inspire in her, she "want[s] everyone whom Our Lord let[s] me encounter to experience this love.. ${ }^{, 69}$ 
Yet, while the primary aim of de l'Incarnation's apostolic mission is the reproduction of a religious identity, rather than a national one, we must recognize that the two identities were closely linked for her. While her figure of a mother suckling her child may call forth the beatific vision of Leonardo da Vinci's Madonna Litta, it has as much to do with an assimilationist colonial impulse as any of Sir Walter Raleigh's sexual puns. From the very beginning of their colonization of the North America, as Vincent Grégoire notes, the French had held out two complementary goals for the New World "Savage": "sauver ce barbare de la perdition [et] en faire un Français d'adoption" ["to save this barbarian from perdition [and] make of him an adopted Frenchman"]. ${ }^{70}$

In a letter to her son, de l'Incarnation affirms this dual mission, telling him that the French have selected several Huron girls who, having already converted to Christianity, are to be raised "à la Françoise" and "francisées tant de langage que de mœurs," with the ultimate goal being their complete incorporation into French society through marriage. ${ }^{71}$ When compared with the English colonial practice of discouraging intermarriage between Native Americans and colonists, except where it served a strategic purpose, the French policy of actively encouraging such intermarriage may seem truly enlightened. Still, de l'Incarnation's letter exposes the preconditions of such intermarriage: religious conversion and national assimilation.

In truth, the basic mechanism of de l'Incarnation's educational rhetoric makes all Native Americans, not only the young girls who were educated at the Ursuline mission, into symbolic children. In a letter the Mother Superior of the Ursulines in Tours, de l'Incarnation writes that the Native American converts are neither "si subtils ny si rafinez" ["as subtle or as refined"] as 
Christians in France, but that they make up for it with "une candeur d'enfant" ["the candour of a child"]. ${ }^{72}$ In her rhetoric here de l'Incarnation firmly abides by the savage/civilized opposition that Grégoire identifies as characteristic of early French missionaries in Canada, reinforcing the subordinate position of Native Americans in relation to the European colonists at the same time as she praises them for their childlike candor.

And yet, de l'Incarnation's rhetoric of familial education opens her up to a reciprocity that begins to flatten such distinctions, much as Bradstreet's comes to flatten those of gender and generation. If the Native Americans are reduced to children in the logic of the passage above, she is reduced to still less when she commands her son to notice that "nôtre propre amour [de Dieu] nous rend esclaves \& nous reduit à rien.” In this same letter to her son, she tells him how happy she would be "si un jour on me venoit dire que mon Fils fût une victime immolée à Dieu!" [“Our proper love [of God] renders us slaves and reduces us to nothing"] ${ }^{73}$ Several years later, De l'Incarnation relates to her son the martyrdom of an Algonquian man, calling him "mon fils spirituel" ["my spiritual son"], pointing out that he "m'aimoit autant au plus que sa Mère" ["loved me as much or more than his own mother"] and that in heaven he will act as "mon Père et mon Avocat auprès de Dieu" ["my father and my advocate with God"]. ${ }^{74}$ In this way de l'Incarnation's spiritual son serves not only as a model for the physical son, but also becomes a father to his spiritual mother because of his successful translation from this world to the next.

The substitutional logic evinced in this letter lends credence to Bruneau's observation that de l'Incarnation's relationship with God is structurally identical to her relationship with her Native American students, which Bruneau characterizes in the binary terms of "same" and "other." " In 
her relationship with God, it is Marie herself who occupies the position of "other," striving to make herself worthy of, and thereby identical to, God; in her relationship with her students, however, the students take the place of the other, and she expects them to strive to be like her, devoting themselves completely to the service of God and the spread of Christianity among their people. As Bruneau notes, this binary logic depends on assimilation and annihilation, whereby the difference of the other comes to be dissolved in the sameness of the same. Thus, de l'Incarnation insists in her Retraites: “je n'avois point d'autre desir que d'étre entierement aneantie en luy [Dieu]" ["I have no other desire than to be totally annihilated in God"]; ${ }^{76}$ similarly, she conceives of the religious conversion of the Native American girls as a loss of self, noting of Marie Negabamat, one of her earliest pupils, that "[e]lle ne sembloit plus être ellemême" ["[s]he seemed no longer to be herself"] when she finally turned to "la prière et aux practiques de la piété Chrétienne" ["prayer and the practices of Christian piety"]. ${ }^{77}$ Expressed in these terms, Marie de l'Incarnation's interaction with her native pupils entirely conforms to Grégoire's worst suspicions about the ethnocentrism of French missionary practice.

Nevertheless, de l'Incarnation's shifting position within these parallel binaries destabilizes them: inasmuch as she herself occupies the position of other vis-à-vis God, she becomes capable of relating to her students as equals on a symbolic level, and of identifying with them. Thus, over the course of her life in Québec, de l'Incarnation becomes a more sensitive observer of Native American customs. At the outset, she emphasizes their "salleté insupportable" ["unbearable filth"], noting "la vermine causée par l'abondance ... de la graisse dont leurs parens les oignent par tout la corps" ["the vermin caused by th[e] abundance of grease [that] their parents rub all over their bodies"], but she also undertakes to learn their languages_-first Algonquian, then later 
Huron, Montagnais, and Iroquois. ${ }^{78}$ While learning their languages, she absorbed their cultural practices, learning not only how to make sagamité, a porridge of corn flavored with bear grease, but also to make extra for when guests arrive unannounced, since they too will expect to receive hospitality. ${ }^{79}$ In the process, however, de l'Incarnation's attachment to French modes of life lessens somewhat, and, as Bruneau notes, she becomes more capable of resisting European conceptions of femininity. ${ }^{80}$

While Grégoire insists that the Christianization of the natives goes hand-in-hand with their civilization and Frenchification — terms which Cardinal Richelieu had laid out in 1627, and which were explicitly part of de l'Incarnation's religious vow — this shift on Marie's part speaks to a troubling of her straightforward identification with her own nation. Ultimately, however, de l'Incarnation's acceptance of Native American customs is limited. A letter she wrote in 1668, nearly 30 years into her mission and only four before her death, speaks to this duality. In it de l'Incarnation returns to the subject of removing grease from the native children when they enter the cloister, stating that "ilz se graissent tous à cause qu'ilz ne portent point du linge" ["since they do not wear any underwear they grease themselves instead"]; ${ }^{81}$ where, in her early letters, the grease had been conceived of in opposition to European under-clothes - encouraging vermin, rather than inhibiting them - they are now seen as parallel—something that can be "worn" in the place of underwear. Lest we be tempted to overstate the importance of this shift in attitude, however, de l'Incarnation ends her letter by emphasizing the difficulty of converting the Native Americans because of the incommensurability of their belief systems, noting that "ce sont gens très susperticieux qui font leur créance en leurs songes" ["they are a very superstitious people who put belief in their dreams"]. ${ }^{82}$ 
Given our knowledge of the faith de l'Incarnation put in her own dreams, it is perhaps unnecessary to point out how blatantly unfair this judgment seems. How could a woman who openly acknowledges that a dream drove her to abandon her family and then her nation in a quest to "build a house for Mary and Jesus" reject another's belief in dreams? At one level the answer is obvious: it is because she sees her dream as a vision sent to her by God, whereas the dreams of Native Americans are mere dreams. At another, perhaps slightly less obvious level, however, de l'Incarnation rejects the native acceptance of dreams precisely because they could be seen as equivalent to her own, which would mean that their religious beliefs were as valid as hers. Putting these two levels together, we see that de l'Incarnation may have been willing to cede aspects of her national identity as a result of her intercultural encounter, but remained steadfast in her religious beliefs, placing them above and beyond any criticism from, or even any engagement with, their counterparts in Native American culture: "[i]lz ont ... créances aux sorciers et devins" ["they believe in sorcerers and diviners"], she writes, but "ce n'est pas qu'ilz soient, [ils] sont des jongleurs ... comme sont les lataleurs en l'Europe" ["they are not really sorcerers; they are jugglers [that is, jokers or con artists] like the buffoons in Europe,’]. ${ }^{83}$

\section{$* * * * *$}

Thus far, I have suggested a fundamental opposition between Bradstreet's insistence on education as the means to ensure the corporate integrity of the family (and by extension the nation and the religion) and de l'Incarnation's on the possibilities of education as a means of expanding the imperial family. In truth, this opposition is more a question of differing emphases 
than differing ends. De l'Incarnation's religious practice leads to an ongoing intellectual and spiritual engagement with her son, thereby maintaining the integrity of her biological family despite the geographical space between them. Meanwhile, Bradstreet, in the conclusion to "Dialogue between Old England and New," envisions the resolution of England's "intestine war" as the precursor to militant English expansion through the renewal of the religious crusades.

Seen thus, Bradstreet and de l'Incarnation are on the recto and verso of the same page, as it were.

Reading Bradstreet and de l'Incarnation together in this fashion exposes Bradstreet's egalitarianism as the obverse of the monoculturalism that undergirds assimilationist colonial expansion. It also draws our attention to how the subordination of national identity to religious identity requires precisely the hollowing out of those identities that Bradstreet performs in her poetry. De l'Incarnation, by contrast, remains too rooted in the ebb and flow of particular customs to ignore the possibility that such identities may remain incommensurate, and thus she finds the links between her religious and national identities beginning to come undone. This undoing, in its turn, points out the problematic symbolic possibilities inherent in Bradstreet and de l'Incarnation's rhetorical linking of sexual and cultural reproduction.

What both of these authors intend is for the literal, embodied family to be raised to the level of the metaphorical, spiritual one; what their writings enable is precisely the opposite. All of the certainty of religious faith begins to devolve upon the biological family, such that it becomes the "nature" of culture. Thus, by insisting on the reproduction of traditional models Bradstreet and de l'Incarnation may have neutralized some of the radically transformational novelty of Bacon's concept of education, yet the recursive symbolic process they engage in allows for the 
literalization and naturalization of what they understood as rhetorical—a possibility that Bradstreet does not seem to have foreseen.

De l'Incarnation, on the other hand, seems to recognize the threat inherent in their rhetoric of familial education:

Nos filles Sauvages externs venant à nos classes, nous leur avons faire voir le mal où elles se precipitant en suivant l'exemple de leur parens, elles n'one pas remis depuis le pied chez-nous. Le naturel des Sauvages est comme cela : ils font tout ce qu'ils voient faire à ceux de leur Nation en matière de moeurs, à moins qu'ils ne soient bien affermis dans la morale Chrétienne. ${ }^{84}$

The purpose behind Bradstreet's and de l'Incarnation's rhetoric thereby produces its own counter-argument: if education, as they have argued, produces identity, then what is to stop the children of French and English colonists from consorting with Native American families and succumbing to "l'appel des bois" ["the call of the wild"] ? ${ }^{85}$

It is precisely this fear of "Indianization," present to a much more limited extent in earlier writing about the dangers of American colonization, that comes to dominate North American writing (and European writing about the Americas, as witnessed by texts like Aphra Behn's The Widdow Ranter) in the years following the publication of The Tenth Muse. ${ }^{86}$ In the wake of King Philip's War, in particular, we find the emergence of the captivity narrative as a means of symbolically confronting this threat by demonstrating the resilience of Anglo-American national 
identity. ${ }^{87}$ Meanwhile, in New France, we find various officials criminalizing the fur trading missions of the coureurs de bois as much because of the perceived moral degeneration of French colonists as because of the commercial threat it poses to the colonial government. ${ }^{88}$ And, at the very same time, we find the persecuted coureur de bois, Pierre Esprit-Radisson, producing an English language manuscript account of his fur trading voyages that focuses on the potent symbolic connections between commercial, familial, and national identities. ${ }^{89}$ Only by analyzing Bradstreet's poetry as part of a larger body of colonial writing, on both sides of the Atlantic, that places family-based education at the center of identity formation, however, can we begin to understand the terms on which these later writers approach this troubled terrain.

${ }^{1}$ Wendy Martin, An American Triptych: Anne Bradstreet, Emily Dickinson, Adrienne Rich (Chapel Hill, N.C.: University of North Carolina Press, 1984), 67.

${ }^{2}$ Adrienne Rich, "Foreword," in Jeannine Hensley, ed., The Works of Anne Bradstreet (Cambridge, Mass.: Belknap Press, 1967), xii-xiv.

${ }^{3}$ Ivy Schweitzer, The Work of Self-Representation: Lyric Poetry in Colonial New England (Chapel Hill, N.C.: University of North Carolina Press, 1991), 127-180; Philip Round, By Nature and by Custom Cursed: Transatlantic Civil Discourse and New England Cultural Production, 1620-1600 (Hanover, N.H.: University Press of New England, 1999), 153-204.

4 “"Now sisters ... impart your usefulnesse, and force': Anne Bradstreet's feminist functionalism in The Tenth Muse (1650)," Early American Literature 35,1 (2000): 5.

${ }^{5}$ Round, I should note, initially emphasizes Bradstreet's place in a community of readers by examining her poems' circulation in manuscript form among a coterie made up of neighbors and relatives. By the conclusion of his chapter on Bradstreet's poetry, however, Round has 
effectively returned Bradstreet to the position of an isolated individual female author, by arguing that her published poems have been submerged in a larger body of predominantly, if not exclusively, male-authored political writing.

${ }^{6}$ Indeed, one of the ironies of Martin's insistence on the pivotal role of "The Author to her Book" is that the same symbolism of author as parent to a book-child is used by any number of contemporary English authors on both sides of the Atlantic, including another Anglo-American colonist, George Alsop, in his A Character of the Province of Mary-Land (London, England: $\mathrm{T}$ [homas] J[ohnson] for Peter Dring, at the sign of the Sun in the Poultrey, 1666).

${ }^{7}$ Marie de l'Incarnation was born as Marie Guyart in Tours in 1599. At the age of seventeen she married a master silkworker, Claude Martin, at her parents' behest and contrary to her own desire to become a nun. A mere two years later, de l'Incarnation was both a mother and a widow, moving in with her sister and brother-in-law in 1625 in order to manage their burgeoning import/export business. De l'Incarnation's religious fervor, however, had hardly weakened, and, after a series of religious visions, she became an Ursuline nun in 1631. At that time her son, named Claude after his father, was only eleven years old. Perhaps unsurprisingly, he reacted poorly to what he perceived as abandonment: running away from home, appearing at the monastery to demand his mother's "return," even getting himself expelled from boarding school. Soon after the completion of her novitiate, de l'Incarnation expressed a desire to engage in missionary work, ultimately receiving permission to travel to Canada in order to establish a teaching mission in Québec; meanwhile her son remained in France, receiving a religious education, and becoming a Benedictine soon after his mother's arrival in Canada. De l'Incarnation died, in Québec, in 1672, having spent a full thirty-three years in service of her mission to educate Native American girls and convert them to Christianity. In the dozen years 
following her death, her son published a series of works containing her writings: La vie de la venérable mère Marie de l'Incarnation (Paris: Louis Billane, 1677), Lettres de la venérable mère Marie de l'Incarnation (Paris: Louis Billane, 1681), Retraites de la venérable mère Marie de l'Incarnation (Paris: Louis Billane, 1682), and L'école sainte ou Explication familière des mystères de la foy (Paris: Jean Baptiste Coignard, 1684).

${ }^{8}$ Carla Zecher, "Life on the French-Canadian Hyphen: Nation and Narration in the Correspondence of Marie de l'Incarnation,” Québec Studies, 26 (Fall 1998/Winter 1999): 39.

${ }^{9}$ Throughout the seventeenth century, the terms "creole" and "criollo" were used in English almost exclusively to refer to Spaniards and Africans born in the Americas. Only by the end of the century did authors like Ned Ward apply it, in a pejorative sense, to American-born English. Meanwhile, the term créole did not find its way into any major seventeenth century French dictionary, including the first edition of the Dictionnaire de l'Académie française (Paris: Jean Baptiste Coignard, 1694).

${ }^{10}$ Anne Bradstreet, Complete Works, eds. Joseph R. McElrath, Jr. and Allan P. Robb. (Boston, Mass.: Twayne, 1981), 177.

${ }^{11}$ Bradstreet, Complete Works, 526.

${ }^{12}$ Bradstreet, Complete Works, 178.

${ }^{13}$ Bradstreet, Complete Works, 177-8

${ }^{14}$ Patricia Pender, "Disciplining the Imperial Mother: Anne Bradstreet's 'A Dialogue between Old England and New,"” in Jo Wallwork and Paul Salzman, eds., Women Writing: 1550-1750 (Bundoora, Australia: Meridian, 2001), 115-31; Louis Montrose, “The Work of Gender in the Discourse of Discovery," in Stephen Greenblatt, ed., New World Encounters (Berkeley: University of California Press, 1993), 177-217. 
${ }^{15}$ Francis Bacon, New Organon (1620), ed. Fulton H. Anderson (Indianapolis, Ind.: BobbsMerrill Educational Publishing, 1960), 34.

16 Mère Marie de l'Incarnation, Correspondance, ed. Dom Guy Oury (Solesmes, France: Abbaye Saint-Pierre, 1971), 129. This and all further translations are my own, unless another English-language source is cited. Further, several of my citations from de l'Incarnation's autobiography are in English alone because the only French edition I could locate, La relation autobiographique de 1654, ed. Dom Guy Oury (Solesmes, France: Abbaye Saint-Pierre, 1976), turned out to be a redaction of the complete text.

${ }^{17}$ Bhabha identifies two opposing modes of signification at work in the articulation of national identity - the pedagogical and the performative. The pedagogical, Bhabha states, is characterized by its "continuist, accumulative temporality," while the performative is "repetitious" and "recursive" (297). The power of the performative, in Bhabha's formulation, is that it interrupts the continuous narrative of pedagogical time, producing a disjunctive temporality that allows for the emergence, or preservation, of alternative representations of national identity. Bhabha's opposition, though it comes from his analysis of the representation of the modern nation-state, is useful to me here because it clarifies the difference between Bacon's conception of education and those of Bradstreet and de l'Incarnation, and thereby allows us to better understand the implications of their gendering and domesticating of the educational process. Homi Bhabha, "DissemiNation: time, narrative, and the margins of the modern nation," in Nation and Narration, ed. Homi Bhabha (London: Routledge, 1990).

${ }^{18}$ Homi Bhabha, “DissemiNation,” 299.

${ }^{19}$ James Egan, Authorizing Experience (Princeton, N.J.: Princeton University Press, 1999), 89. 
${ }^{20}$ Bradstreet, Complete Works, 179.

${ }^{21}$ Gary Schneider, “Affecting Correspondences: Body, Behavior, and the Textualization of Emotion in Early Modern English Letters," Prose Studies 23,3 (Dec 2000): 33.

${ }^{22}$ Gina Bloom, “"Walk in Darkness': The Practice of Duty in Anne Bradstreet's Marriage

Poems," Literature and Belief 16,1 (1996): 116.

${ }^{23}$ Bloom, "“Walk in Darkness': The Practice of Duty in Anne Bradstreet's Marriage Poems," Literature and Belief 16,1 (1996): 123.

${ }^{24}$ Bloom, “'Walk in Darkness': The Practice of Duty in Anne Bradstreet's Marriage Poems," Literature and Belief 16,1 (1996): 117, following 1 Corinthians 7:2.

${ }^{25}$ Bradstreet, Complete Works, 179.

${ }^{26}$ Bloom, "“Walk in Darkness': The Practice of Duty in Anne Bradstreet's Marriage Poems," Literature and Belief 16,1 (1996): 116.

${ }^{27}$ Bradstreet, Complete Works, 181.

${ }^{28}$ Bloom, "“Walk in Darkness': The Practice of Duty in Anne Bradstreet's Marriage Poems," Literature and Belief 16,1 (1996): 119.

${ }^{29}$ Bradstreet, Complete Works, 187.

${ }^{30}$ Bradstreet, Complete Works, 189.

${ }^{31}$ Edmund S. Morgan, The Puritan Family: Religion and Domestic Relations in Seventeenth Century New England, $2^{\text {nd }}$ ed (New York: Harper \& Row, 1966), 91.

${ }^{32}$ David Levin, Cotton Mather: The Young Life of the Lord's Remembrancer, 1663-1703

(Cambridge, Mass.: Harvard University Press, 1978), 194-5.

${ }^{33}$ Bradstreet, Complete Works, 206.

${ }^{34}$ Bradstreet, Complete Works, 165, 167. 
${ }^{35}$ Bradstreet, Complete Works, 166.

${ }^{36}$ Bradstreet, Complete Works, 195.

${ }^{37}$ Bradstreet, Complete Works, 196. See also 198, 200.

${ }^{38}$ Max Weber, The Protestant Ethic and the Spirit of Capitalism, trans. Talcott Parsons (New York: Charles Scribner's Sons, 1952); Nancy Armstrong and Leonard Tennenhouse, The Imaginary Puritan: Literature, Intellectual Labor, and the Origins of Personal Life (Berkeley: University of California Press, 1992).

${ }^{39}$ Egan, Authorizing Experience, 88.

${ }^{40}$ Bradstreet, Complete Works, 176.

${ }^{41}$ Bradstreet, Complete Works, 48, 50.

${ }^{42}$ Virgil, Georgics, trans. Janet Lembske (New Haven, Conn.: Yale University Press, 2005), 19-20.

${ }^{43}$ Bradstreet, Complete Works, 13.

${ }^{44}$ The central place of Virgil's entire corpus, especially the Georgics, has been most recently (and convincingly) been made by Andrew Wallace in his "Virgil and Bacon in the Schoolroom." English Literary History, 73,1 (2006): 161-185.

${ }^{45}$ Barbara J. Baines. Representing Rape in the English Early Modern Period (Lewiston, N.Y.: Edwin Mellen Press, 2003), 160.

${ }^{46}$ Bradstreet, Complete Works, 72.

${ }^{47}$ Bradstreet, Complete Works, 144.

${ }^{48}$ Indeed, the figure of the sovereign's body composed out of its subjects would serve, the year after the first publication of Bradstreet's poems, as the eponymous frontispiece for Thomas 
Hobbes' Leviathan (London: Printed for Andrew Crooke, at the Green Dragon in St. Paul's Churchyard, 1651).

${ }^{49}$ Egan, Authorizing Experience, 93.

${ }^{50}$ Cotton Mather, Decennium luctuosum: An history of remarkable occurrences, in the long war, which New-England hath had with the Indian salvages, from the year, 1688. To the year 1698, (Boston: B[artholomew] Green and J[ohn] Allen, 1699), 212.

${ }^{51}$ Marie-Florine Bruneau, Women Mystics Confront the Modern World (Albany: State University of New York Press, 1998); Natalie Zemon Davis, Women on the Margins: Three Seventeenth Century Lives (Cambridge, Mass.: Harvard University Press, 1995).

${ }^{52}$ Mère Marie de l'Incarnation, Selected Writings, ed. Irene Mahoney (New York: Paulist Press, 1989), 95.

53 de l'Incarnation, Selected Writings, 95.

${ }^{54}$ de l'Incarnation, Selected Writings, 97.

55 de l'Incarnation, Correspondance, 130-31.

${ }^{56}$ Bruneau, Women Mystics, 75.

${ }^{57}$ Davis, Women on the Margins, 75.

58 de l'Incarnation, relation autobiographique, 93; de l'Incarnation, Selected Writings, 116.

For the complete dream vision see de l'Incarnation, relation autobiographique, 86-88 and Selected Writings, 108-110.

${ }^{59}$ de l'Incarnation, Retraites, 243.

${ }^{60}$ de l'Incarnation, Correspondance, 240; Mère Marie de l'Incarnation, Word from New France: Selected Letters, ed. and trans. Joyce Marshall (Toronto: Oxford University Press, 1967), 232. 
61 "Thus I know of no other book in this genre that is easier to use. Those who wish to make something of it have but to follow she who wrote it: they can think what she thought, produce the effects that she produced, make the resolutions that she made, speak to God as she spoke, to fill themselves with her spirit and her sentiments. In the end they will make the same prayers that she made, and it would be difficult to make any more sacred and pure than those" (translation mine); Claude Martin, "Preface," in Retraites de la venérable mère Marie de l'Incarnation (Paris: Louis Billane, 1682), a iii.

${ }^{62}$ Claude Martin, La vie, a2v; Davis, Women on the Margins, 104.

${ }^{63}$ Claude Martin, La vie, a2v.

${ }^{64}$ de l'Incarnation, relation autobiographique, 22; de 1'Incarnation, Selected Writings, 44.

${ }^{65}$ de l'Incarnation, relation autobiographique, 23, 25; de l'Incarnation, Selected Writings, $44-45,47$.

${ }^{66}$ de l'Incarnation, relation autobiographique, 25; de 1'Incarnation, Selected Writings, 47.

${ }^{67}$ de l'Incarnation, Selected Writings, 42.

${ }^{68}$ de l'Incarnation, relation autobiographique, 25; de 1'Incarnation, Selected Writings, 47.

${ }^{69}$ de 1'Incarnation, Selected Writings, 45.

70 Vincent Grégoire, "Ethnocentrisme, pratique pédagogique et missionnaire dans la correspondance de la mère ursuline Marie de l'Incarnation,” Französisch Heute, 27,3 (Sept 1996): 214.

${ }^{71}$ de 1'Incarnation, Correspondance, 545-6. The passage reads, in English, "We have some Huron pupils whom the Fathers have thought appropriate to raise in the French manner, for since all of the Hurons are presently converted and dwell near the French, it is felt that in time it would 
be possible for the French to marry these Huron girls. This could not take place unless the girls were French not only in language but also in custom," de l'Incarnation, Selected Writings, 252-3.

${ }^{72}$ de l'Incarnation, Correspondance, 139.

73"; " "How happy would I be if one day if someone came to tell me that my son had been immolated as a victim to God" (translations mine); de l'Incarnation, Correspondance, 184.

${ }^{74}$ de l'Incarnation, Correspondance, 399; de l'Incarnation, Selected Writings, 246.

${ }^{75}$ Marie-Florine Bruneau, "Marie de l'Incarnation, L'Anthropologie mystique" in Bernard Beugnot, ed., Voyages, récits et imaginaire (Seattle: Papers on French Seventeenth Century Literature, 1984), 189.

${ }^{76}$ de l'Incarnation, Retraites, 82-83.

${ }^{77}$ de l'Incarnation, Correspondance, 95; de l'Incarnation, Word from New France, 71.

${ }^{78}$ de 1'Incarnation, Correspondance, 97; de l'Incarnation, Word from New France, 75)

${ }^{79}$ de l'Incarnation, Correspondance, 97; de l'Incarnation, Word from New France, 74).

${ }^{80}$ Indeed, de l'Incarnation's identification with her pupils was further fueled by a transethnic solidarity of sex. Bruneau singles out a particular incident that speaks directly to this solidarity, when a young native woman was publicly whipped by her converted family members as punishment for a presumed meeting with an illicit suitor. While the Jesuit Father de Quen acceded to the family's desire to punish the girl, and then refused to baptize her because he assumed she was guilty, de l'Incarnation believed the girl and "accuse[d] [Father de Quen] of having acted without giving the matter due consideration and without having enquired into the facts" (Bruneau, Women Mystics, 97). She then spread her version of the story, which contradicts the one recorded in the Jesuit Relations. This identification with her fellow women also leads de l'Incarnation to oppose the sexually violent behavior of European men to the 
civility of their Native American counterparts. Thus, in one letter to her son, she notes that she need not fear any sort of violation at the hands of Iroquois warriors, as she might from French soldiers, and, in another, she emphasizes the importance of the Ursuline cloister as a safe-house for young girls who, "quelqu'âge qu'elles ayent, ... sont dans un danger évident" from the sexual aggression of the excess men in the colony (de l'Incarnation, Correspondance, 802).

${ }^{81}$ de l'Incarnation, Correspondance, 852); de l'Incarnation, Selected Writings, 273.

${ }^{82}$ de l'Incarnation, Correspondance, 855; de l'Incarnation, Selected Writings, 274.

${ }^{83}$ de l'Incarnation, Correspondance, 855; de l'Incarnation, Selected Writings, 275.

${ }^{84}$ de l'Incarnation, Correspondance, 681; "When our Indian day pupils came to our classes we tried to get them to see the trouble they would be in if they followed the example of their relatives; since then they have not set foot in our place. This is the nature of the savages. They do everything they see the people of their nation doing where morals are concerned unless they have been solidly strengthened in Christian morality," de l'Incarnation, Selected Writings, 262.

${ }^{85}$ Bruneau, “Anthropologie mystique," 181.

${ }^{86}$ Mather, Decennium luctuousum, 211.

${ }^{87}$ See, for example, Teresa Toulouse's "The Sovereignty and Goodness of God in 1682: Royal Authority, Female Captivity, and 'Creole’ Male Identity,” English Literary History 67,4 (Winter 2000): 925-949, which argues that Mary Rowlandson's seminal captivity narrative, The Soveraignty and goodness of God (Cambridge, Mass.: Samuel Green, 1682), occupied a key place in the discursive construction of a normative Anglo-American male identity.

${ }^{88}$ As the Canadian historian W. J. Eccles notes, the burgeoning of the fur trade led to a crisis in the labor force of New France because it drew away large numbers of productive young men. See The French in North America (East Lansing: Michigan State University Press, 1998), 94. 
Elsewhere, Eccles notes the deleterious effects that the colonial authorities believed were produced by their strong ties with Native Americans: "The missionaries ... were aghast at their adoption alike of Indian virtues and vices, and some of the royal officials expressed alarm at the effect they had on colonial society" (The Canadian Frontier (New York: Holt, Rinehart, and Winston, 1969), 8). By the turn of the eighteenth century, however, France had realized the importance of their fur-trade alliances as a means of preventing the English from colonizing the interior of the continent, and Louis XIV ordered the creation of the colony of Louisiana to ensure French control of the Mississippi Valley. See W. J. Eccles, "The Fur Trade and Imperialism,” in Alan L. Karrras and J. R. McNeill, eds., Atlantic American Societies (New York: Routledge, 1992), 212-241).

${ }^{89}$ For the most complete and current account of the production of Radisson's manuscript see Germaine Warkentin's “Who Was the Scribe of the Radisson Manuscript?” Archivaria 53 (Spring 2002): 47-63, which revisits several of the conclusions of her previous article, “Radisson’s Voyages and Their Manuscripts," Archivaria 48 (Fall 1999): 199-222. Martin Fournier, in his biography of Radisson, Pierre-Esprit Radisson, aventurier et commerçant. (Sillery, Que.: Septentrion, 2002), offers the alternative hypothesis that Radisson's manuscript was prepared at the request of the Royal Society. Fournier's biography is available in English as Pierre-Esprit Radisson, 1636-1710 (Sillery, Que.: Septentrion, 2003). While I find Warkentin's account more compelling because of her painstaking forensic analysis of the manuscript itself, Fournier's thesis is at least plausible given that Radisson's ethnographic and geographical knowledge of the interior of the North American continent was, at that time, unsurpassed by any other European. 